Prayoga, M.K. $\cdot$ N. Rostini $\cdot$ M. R. Setiawati $\cdot$ T. Simarmata $\cdot$ S. Stoeber $\cdot$ K. Adinata

\title{
Preferensi petani terhadap keragaan padi (Oryza sativa) unggul untuk lahan sawah di wilayah Pangandaran dan Cilacap
}

\section{Preferences of farmers to superior rice (Oryza sativa) for rice fields in Pangandaran and Cilacap regions}

Diterima : 13 Februari 2018/Disetujui : 13 Maret 2018 / Dipublikasikan : 31 Maret 2018

CDepartment of Crop Science, Padjadjaran University

\begin{abstract}
The object that conducted in this study is farmer's preferences of rice plant characteristics. This study was taken in 3 villages which are village Ciganjeng, village Pamotan, and village Rawaapu. The method used in this study was quantitative design with descriptive analysis. The respondents were 64 rice plant farmers. Measuring instrument used was questionnaire and interview. The result of this study showed that farmers has its own preference for the character of rice plants. Conclution of this study is farmers preferred rice plants which has an average height of plants, wide leaves, leave's surface, leave's angle, and rice straw's type; rice straw that has many branches; strong braches; has a lot rice grains; maturity of rice plants; lenght and wide grains size; non-aromatic; and tender texture. The farmers thought that leave's surface isn't an important character of a rice plants; high of plants, leave's lenght and wide, leave's angle, rice straw's type, grain's lenght and wide, and rice's scent are quite important characteristics; branch's strenght, grain's quantity, and plant's maturity are an important characteristics; resistance to pests, disease resistance, drought resistance, resistance to inundation, salinity resistance, productivity, and rice texture are the most important characteristics.
\end{abstract}

Keywords : preferences, farmer, superior varieties

\footnotetext{
Dikomunikasikan oleh Ruminta

Prayoga, M.K. ${ }^{1} \cdot$ N. Rostini ${ }^{2} \cdot$ M. R. Setiawati ${ }^{2} \cdot$ T.

Simarmata $^{2} \cdot \mathrm{S}$. Stoeber ${ }^{3} \cdot \mathrm{K}$. Adinata ${ }^{4}$

${ }^{1}$ Mahasiswa Program Doktor Fakultas Pertanian Unpad

${ }^{2}$ Fakultas Pertanian Universitas Padjadjaran

${ }^{3}$ Centre for Rural Development (SLE) Humboldt-

Universität zu Berlin

${ }^{4}$ Ikatan Petani Pengendalian Hama Terpadu Indonesia,

Korespondensi: mkhaisprayoga@yahoo.com
}

Sari Objek yang dikaji dalam penilitian ini adalah preferensi petani terhadap karakter tanaman padi. Tempat penelitian dilaksanakan di 3 desa yaitu Desa Ciganjeng, Desa Pamotan dan Desa Rawaapu. Desain penelitian menggunakan desain kuantitatif dengan pendekatan analisis data secara deskriptif. Metode yang digunakan adalah survey untuk mengumpulkan data dengan mengedarkan kuisioner dan melakukan wawancara. Jumlah petani yang diwawancarai yaitu 64 orang. Hasil dari penelitian ini adalah petani memiliki preferensi tersendiri terhadap karakter tanaman padi. Kesimpulan dari penelitian ini adalah petani lebih menyukai tanaman padi yang memiliki tinggi tanaman, panjang daun, lebar daun, permukaan daun, sudut daun dan tipe malai yang sedang, cabang malai sekunder yang banyak, ketegaran batang yang kuat, jumlah anakan yang banyak, umur yang genjah, ukuran gabah yang panjang dan lebar, aroma yang tidak wangi, serta tekstur nasi yang pulen. Petani beranggapan bahwa karakter permukaan daun merupakan karakter yang tidak penting; karakter tinggi tanaman, panjang daun, lebar daun, sudut daun, tipe malai, panjang gabah, lebar gabah, dan aroma tergolong karakter cukup penting; karakter ketegaran batang, jumlah anakan, dan umur tanaman merupakan karakter yang penting; karakter ketahanan terhadap hama, ketahanan terhadap penyakit, ketahanan terhadap kekeringan, ketahanan terhadap genangan, ketahanan terhadap salinitas, produktivitas, dan karakter tekstur nasi merupakan karakter yang sangat penting.

Kata kunci : preferensi, petani, varietas unggul 


\section{Pendahuluan}

Beras merupakan bahan makanan pokok bagi sebagian besar penduduk Indonesia. Beras merupakan sumber pangan utama yang menyediakan 56 sampai 80\% kebutuhan kalori peduduk Indonesia (Syahri dan Renny, 2013). Kebutuhan beras semakin meningkat seiring dengan bertambahnya jumlah penduduk di Indonesia. Bahkan menurut Adnyana (2004) pada tahun 2025 diperkirakan lebih dari 5 milyar. Muncul kekhawatiran akan terjadinya keadaan krisis pangan di masa datang jika ketersediaan pangan tidak mampu mengimbangi meningkatnya kebutuhan pangan. Tingkat pendidikan dan kesejahteraan masyarakat juga turut mempengaruhi peningkatan konsumsi perkapita untuk berbagai jenis pangan. Berbagai faktor tersebut menjadikan Indonesia harus terus mengupayakan ketersediaan pangan, sehingga dari sisi Ketahanan Pangan Nasional, tanaman padi fungsinya menjadi amat penting.

Berbagai upaya telah dilakukan guna meningkatkan produksi beras nasional salah satunya adalah penggunaan varietas unggul hasil pemuliaan. Penggunaan varietas unggul merupakan salah satu faktor penting yang mempengaruhi produksi pertanian dan berperan strategis dalam menunjang keberhasilan pertanian Indonesia. Penggunaan varietas unggul akan menjamin peningkatan kualitas hasil panen yang dapat meningkatkan kesejahteraan petani serta membantu program pemerintah dalam swasembada beras (Ningsih dan Dwi, 2017). Menurut Baihaki dan Wicaksana (2005), bagi negara berkembang memang lebih dibutuhkan varietas yang dapat beradaptasi luas karena mudah dalam pengadaan dan pengendalian secara nasional, akan tetapi pengembangan varietas yang beradaptasi luas memiliki kelemahan fundamental khususnya dalam mengahadapi gangguan hama dan penyakit.

Bagi negara-negara yang variabilitas biogeofisiknya luas seperti Indonesia, pemulia dapat memanfaatkan potensi lingkungan spesifik dalam penentuan penerapan kebijakan wilayah sebaran suatu varietas unggul baru. Alternantif yang cukup menguntungkan adalah dengan merakit varietas unggul baru yang memiliki potensi hasil yang tinggi pada wilayah tumbuh yang spesifik (spesifik lingkungan tumbuh - spesific adaptability). Menurut Baihaki dan Wicaksana (2005), varietas seperti itu memiliki potensi hasil yang tinggi pada lingkungan tumbuh tertentu dan mampu memanfaatkan potensi-potensi sumberdaya alam lokal dan bahkan biasanya memiliki produktivitas yang lebih tinggi dibanding varietas yang beradaptasi luas.

Dalam kegiatan merakit varietas-varietas unggul yang spesifik wilayah diperlukan informasi terkait keadaan, kebiasaan, dan kebutuhan petani sehingga perakitan sesuai dengan kebutuhan di tempat tersebut. Menurut Almekinders dan Elings (2001), pada era market driven, semua proses produksi mengacu pada pemuasan kebutuhan pasar, sehingga keputusan menentukan nilai produk akhir melibatkan opini konsumen. Demikian pula pada proses pemuliaan tanaman sejak satu dekade terakhir mulai berkembang konsep pemuliaan yang melibatkan pelaku produksi lapang dan konsumen dalam hal ini adalah petani.

Tanpa partisipasi petani program pemuliaan untuk keperluan lokal tidak akan mencapai sasaran. Dipercaya bahwa pemuliaan berbasis partisipasi pengguna memiliki kelebihan mendasar, seperti definisi kriteria seleksi yang sesuai untuk kebutuhan lokal dan kesesuaian dengan lingkungan target yang lebih baik (Almekinders dan Elings, 2001). Oleh karena itu, diperlukan suatu kajian untuk mengetahui keinginan atau prferensi petani terhadap karakter-karakter padi yang akan dikembangkan oleh seorang pemulia tanaman. Dengan demikian diharapkan pemuliaan tanaman padi akan lebih terarah sesuai dengan kebutuhan.

Tujuan dari penelitian ini adalah untuk mengetahui preferensi petani terhadap keragaan morfologi tanaman padi yang ideal. Dengan demikian diharapkan kegiatan pemuliaan tanaman padi lebih terarah berdasar pada keinginan konsumen dalam hal ini adalah petani.

\section{Bahan dan Metode}

Metode yang dipergunakan dalam kajian ini adalah metode kulitatif deskriptif. Objek yang dikaji dalam penelitian ini adalah preferensi petani terhadap karakter tanaman padi. Tempat penelitian dilaksanakan di tiga desa yaitu Desa Ciganjeng, Desa Pamotan dan Desa Rawaapu. Pemilihan lokasi ditentukan berdasarkan pertimbangan bahwa ketiga Desa tersebut merupakan salah satu sentra produksi padi. Selain itu, ketiga Desa tadi memiliki keunikan 
dalam permasalahan yang mereka hadapi dalam budidaya tanaman padi yaitu cekaman salinitas dan genangan. Hal tersebut menjadi menarik karena preferensi petani terhadap karakterkarakter tanaman padi diharapkan akan berbeda. Jumlah petani yang diwawancarai yaitu 64 orang tersebar di tiga desa (desa Ciganjeng, desa Pamotan, dan desa Rawaapu). Alat yang dipergunakan yaitu alat tulis, kuisioner, dan kamera digital. Data yang diperoleh selanjutnya dianalisis menggunakan software SPSS.

\section{Hasil dan Pembahasan}

Varietas Padi Yang Banyak Dipergunakan. Terdapat sepuluh varietas yang diperguanakan oleh petani yaitu Cigeulis, Ciherang, Inpari 32, Inpari 10, IR 64, Cilamaya muncul, Putra mandiri, Pasundan, Putra haji, dan Sri ayu. Varietas yang paling banyak dipergunakan oleh petani adalah varietas Ciherang sebanyak $45,31 \%$ dan terbanyak kedua adalah IR 64 sebanyak $18,75 \%$ (Tabel 1). Varietas ciherang dan IR64 merupakan varietas yang sangat familiar dan banyak ditanam diberbagai daerah di Indonesia. Menurut hasil penuturan terhadap responden, pemilihan varietas Ciherang untuk ditanam karena varietas Ciherang menghasilkan beras yang pulen dan enak, mampu beradaptasi di segala tempat kondisi alam, umurnya yang relatif lebih singkat serta produktivitasnya cukup tinggi. Sama halnya dengan Ciherang, varietas IR 64 pun memiliki keunggulan wilayah adaptasi luas dan produktivitas tinggi, sehingga banyak petani yang menanam varietas tersebut. Selain itu kedua varietas itu mudah ditemukan dan diperoleh, sehingga para petani tidak sulit untuk mendapatkannya.

Tabel 1. Varietas Padi yang Banyak Ditanam oleh Petani.

\begin{tabular}{lcc}
\hline Varietas & Frekuensi & Persentasi \\
\hline Cigeulis & 1 & 1,56 \\
Ciherang & 29 & 45,31 \\
Inpari 32 & 2 & 3,13 \\
Inpari 10 & 2 & 3,13 \\
IR 64 & 12 & 18,75 \\
Cilamaya muncul & 4 & 6,25 \\
Putera mandiri & 1 & 1,56 \\
Pasundan & 4 & 6,25 \\
Putera haji & 8 & 12,50 \\
Sri ayu & 1 & 1,56 \\
\hline
\end{tabular}

Dari ke sepuluh varietas yang ditanam oleh petani terdapat satu varietas lokal yang cukup digemari oleh petani di daerah pangandaran dan cilacap yaitu varietas Putra haji. Belum diketahui secara jelas asal usul varietas itu, namun sudah berkembang dan banyak ditanam oleh petani sekitar. Varietas Putra haji memiliki pnampilan tanamn yang cukup baik. Tinggi varietas itu berkisar antara $110-130 \mathrm{~cm}$, tipe malai sedang (Gambar 1a), cabang malay sekunder banyak (Gambar 1b), jumlah anakan banyak berkisar anatara $20-25$ anakan, tipe gabah panjang dan sempit, tekstur nasi pulen, serta diklaim cukup adaptif pada kondisi lahan di desa Ciganjeng, Pamotan, dan desa Rawaapu yang sering tergenang dan memiliki tingkat salinitas yang cukup tinggi. Dari hasil survey $14 \%$ petani mengungkapkan bahwa varietas lokal Putra haji unggul dibanding varietasvarietas lain yang pernah mereka tanam.

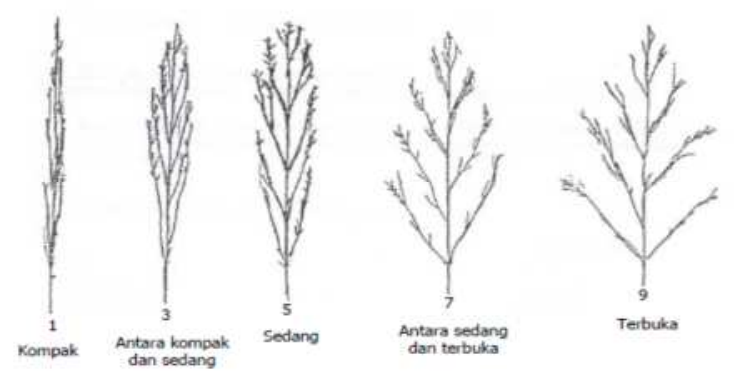

(a)

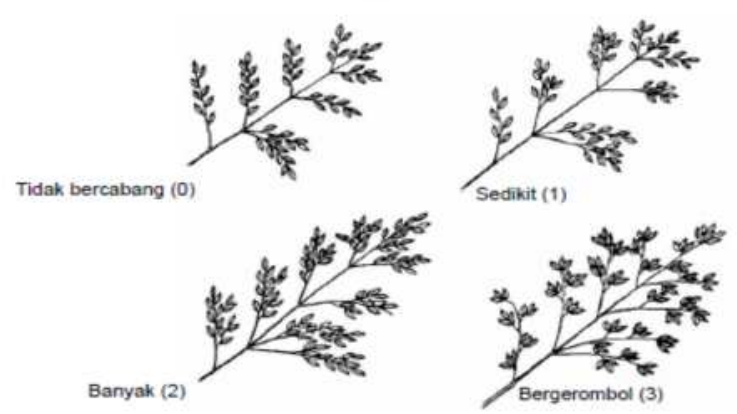

(b)

\section{Gambar 1. (a) Tipe Malai; (b) Cabang Malai Sekunder Sumber: BPPPKNPN (2003)}

Varietas yang ditanam oleh petani belum tentu merupakan varietas yang dianggap memilki hasil terbaik. Hasil survey menemukan bahwa terdapat varietas yang cukup baik dan adaptif terhadap kondisi lingkungan, namun benihnya sulit ditemukan seperti halnya varietas Inpari 10 . Sebanyak $14,06 \%$ petani menuturkan 
bahwa varietas tersebut memiliki produktivitas yang cukup baik dan retalif lebih adaptif terhadap kondisi lingkungan diwilayahnya. Walau demikian benih Inpari 10 sudah mulai langka di pasaran, sehingga petani terpaksa memakai benih varietas lain yang mudah ditemukan, atau terkadang petani memakai varietas tertentu karena adanya bantuan benih dari Dinas Pertanian setempat, penyuluh pertanian, ataupun kelompok tani setempat. Sebanyak $40 \%$ petani responden mempergunaan benih bantuan dari Dinas Pertanian setempat.

Preferensi Petani terhadap Keragaan Padi. Preferensi dapat diartikan kecenderungan dalam memilih atau prioritas yang diinginkan. Preferensi sangat menentukan keputusan konsumen dalam memilih suatu produk, termasuk dalam hal ini keputusan petani dalam pemilihan input usaha taninya. Konsumen dalam mengambil keputusan mengenai produk apa yang akan dibeli atau dikonsumsi akan dipengaruhi oleh beberapa faktor tertentu. ada beberapa faktor yang mempengaruhi minat beli konsumen, yaitu antara lain faktor budaya, faktor pribadi, faktor psikologis dan faktor Sosial Marwan (1990). Dalam hal ini ingin diketahui bagaimana keragaan padi yang ideal dan diinginkan oleh petani di daerah Pangandaran dan Cilacap.

Keragaan yang dimaksud adalah beberapa karakter morfologi dan agronomi yang mengacu pada buku Panduan Sistem Karakterisasi dan Evaluasi Tanaman Padi Badan Penelitian dan Pengembangan Pertanian Komisi Nasional Plasma Nutfah tahun 2003. Terdapat 21 karakter yang menjadi acuan yaitu tinggi tanaman, panjang daun, lebar daun, permukaan daun sudut daun, tipe malay, cabang malay sekunder, ketegaran batang, jumlah anakan, umur tanaman, jumlah biji pertanaman, panjang biji gabah, lebar biji gabah, aroma, ketahanan terhadap hama penyakit, ketahanan terhadap kekeringan, ketahanan terhadap genangan, ketahanan terhadap salinitas, produktivitas, dan kepulenan nasi.

Hasil analisis menunjukkan bahwa sebanyak $75 \%$ petani lebih menyukai tanaman padi dengan ketinggian sedang, yaitu berkisar antara 110-130 $\mathrm{cm}$. Karakter tinggi tanaman merupakan pola adaptasi suatu tanaman dalam mengantisipasi cekaman genangan. Genangan akan memacu elongasi batang sebagai salah strategi penghindaran (escape strategy) terhadap penggenangan untuk membantu mencukupi kebutuhan oksigen dan karbondioksida untuk mendukung respirasi aerob dan fotosintesis (Kawano et al., 2009). Hasil penelitian Rachmawati dan Retnaningrum (2013), menunjukkan bahwa tinggi tanaman padi pada perlakuan genangan relatif lebih tinggi dibandingkan dengan perlakuan tanpa genangan.

Untuk karakter panjang daun dan lebar daun, sebanyak $67 \%$ dan $78 \%$ memilih panjang dan lebar daun yang sedang (Gambar 2). Ukuran daun yaitu panjang dan lebar daun berpengaruh terhadap luas daun. Hasil penelitian Sundari (2012), menjelaskan bahwa luas daun berpengaruh terhadap hasil suatu tanaman. Menurut Kisman, dkk. (2007), luas daun tanaman yang optimal mampu memaksimalkan penyerapan cahaya matahari dalam proses fotosintesis, akan teteapi luas daun yang terlalu besar justru akan mengurangi pitensi penyerapan sinar matahari, karena akan menutupi daun daun lain dibawahnya.

Pada karakter permukaan daun sejumlah $42 \%$ petani memilih permukaan daun yang sedang, 34\% tidak berambut, dan $24 \%$ memilih permukaan daun yang berambut (Gambar 2). Rambut pada permukaan daun marupakan salah satu pola pertahanan tanaman padi terhadap serangan hama. Akan tetapi rambut yang terlalu banyak pada tanaman padai membuat petani kesulitan dalam kegiatan panen. Rambut yang cukup banyak pada permukaan daun padi mengakibatkan gatal pada permukaan kulit petani, sehingga sebagian besar petani memilih permukaan daun yang berambut sedang, karena merupakan salahsatu antisipasi terhadap hama, namun tidak menjadi masalah pada saat panen.

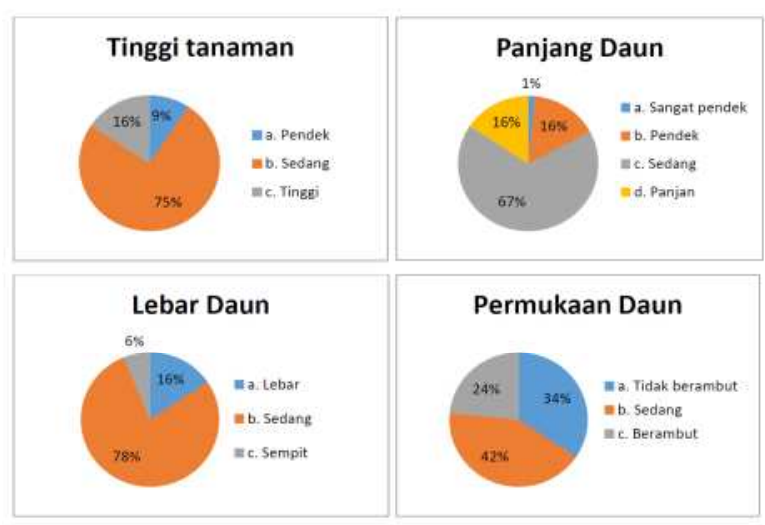

Gambar 2. Preferensi Petani Terhadap Karakter Tinggi Tanaman, Panjang Daun, Lebar Daun, dan Permukaan daun 
Sudut daun berpengaruh terhadap penerimaan cahaya matahari dalam proses fotosintesis. Sudut daun yang semakin sempit mampu memaksimalkan unsur cahaya, sehingga daya hasil tanaman pun akan meningkat (Prayoga, dkk., 2016). Hal tersebut sejalan dengan hasil survey yang dilakukan, sebagian besar responden yaitu 39\% lebih menyukai tanaman padi dengan sudut daun yang tegak, artinya memiliki sudut daun yang sempit agar memkasimalkan unsur cahaya yang nantinya akan diserap daun dalam proses fotosintesis. Walaupun demikian ternyata terdapat 33\% yang lebih menyukai sudut daun yang sedang, dan 28\% menyukai sudut daun mendatar (Gambar $3)$.

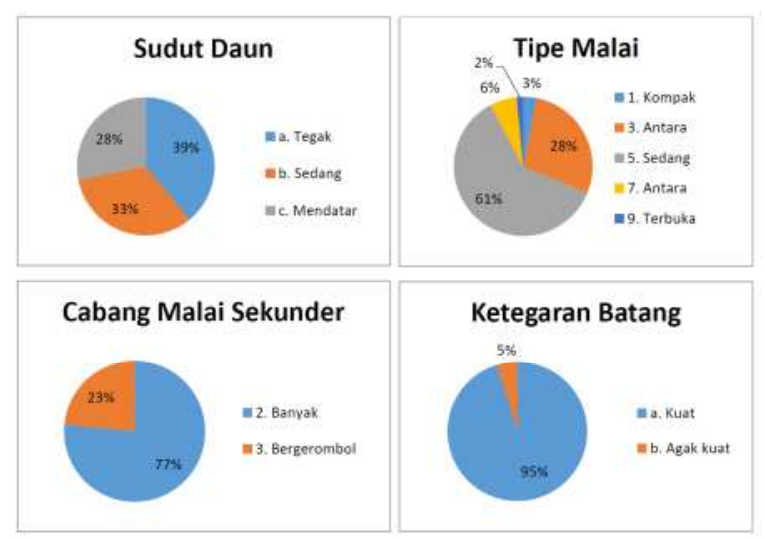

\section{Gambar 3. Preferensi Petani Terhadap Karakter Sudut Daun, Tipe Malai, Cabang Malai Sekunder, dan Ketegaran Batang}

Tipe malai yang paling disukai petani adalah malai yang sedang, yaitu sebanyak $61 \%$ responden (Gambar 3). Hal itu dikarenakan petani responden beranggapan bahwa tipe malai yang sedang akan mampu memaksimalkan hasil karena tidak terlalu memnutup juga tidak terlalu terbuka. Apabila mali tertutup perkembangan gabah akan terganggu, dan apabila malai terlalu terbuka akan memudahkan burung dalam memakan gabah, sehingga menurut petani tipe malai sedang adalah tipe yang ideal. Untuk karakter cabang malai sekunder petani memilih cabang malai sekunder yang bergerombol yaitu sebanyak 77\% (Gambar 3). Orientasi hasil merupakan indikator utama yang menjadi prioritas petani, sehingga petani beranggapan bahwa cabang malai sekunder yang banyak dapat meningkatkan produksi gabah pada tanaman padi.

Karakter lain yang cukup penting adalah ketegaran batang. Sebanyak $95 \%$ petani menyukai tanaman padi dengan ketegaran batang yang kuat. Batang yang kuat dihapkan mampu menjaga tanaman padi agar tetap kokoh saat gabah mulai berisi, karena tak jarang akibat produksi tanaman padi yang tinggi mengakibatkan tanaman padi roboh akibat batang tidak kuat menahan gantungan malai dengan gabah yang banyak. Selain itu batang dengan ketegaran yang kuat mampu memjaga tanaman tetap kokoh saat terjadi angin yang kencang.

Pada karakter jumlah anakan, sebanyak $72 \%$ petani memilih jumlah anakan banyak (2025 anakan per tanaman), 25\% memilih jumlah anakan sangat banyak (lebih dari 25 anakan per tanaman), dan 3\% memilih jumlah anakan sedang (10-19 anakan pertanaman) (Gambar 4). Jumlah anakan merupakan salah satu indikator tanaman padi yang unggul dikalangan petani. Jumlah anakan yang banyak diklaim mampu mengahasilkan kabah yang banyak pula. Akan tetapi pada kenyataannya jumlah anakan yang banyak dapat berpengaruh terhadap kompetisi inter spesies dalam mendapatkan air, unsur hara, $\mathrm{CO} 2, \mathrm{O} 2$, cahaya, dan ruang untuk tumbuh sehingga jumlah anakan yang terlalu banyak malah berpengaruh negatif terhadap produktivitas tanaman padi (Gani, 2003; Abdullah, 2004).

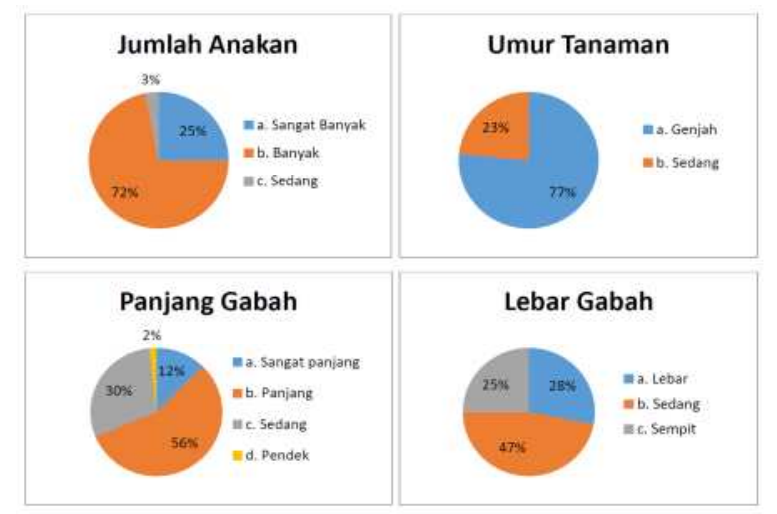

Gambar 4. Preferensi Petani Terhadap Karakter Jumlah Anakan, Umur Tanaman, Panjang Gabah, Lebar Gabah

Pada karakter umur tanaman, petani lebih menyukai tanaman padi yang ber umur genjah. Umur tanaman yang genjah diharapkan mampu memaksimalkan potensi lahan. Dari mulanya petani hanya dapat menanam 2 kali padi dalam satu tahun, mungin dengan umur yang genjah bisa berubah menjadi 3 kali dalam satu tahun. Ataupun petani mampu memaksimalkan potensi 
lahan mereka dengan menanam komoditas lain yang memilki umur lebih pendek.

Produktivitas tanaman padi yang tinggi tidak menjadi pertimbangan utama petani dalam memilih varietas. Ukuran gabah menjadi salah satu pertimbangan. Hal itu terjadi pada varietas Cilamaya muncul, sebanyak 18,75\% petani beranggapan bahwa varietas Cilamaya muncul memiliki produktivitas yang tinggi. Walaupun demikian, ukuran gabah yang pendek dan lebar (sedikit bulat) membuat varietas tersebut jarang ditanam oleh petani. Terbukti hasil survey menunjukkan hanya $6,25 \%$ petani saja yang menanam varietas tersebut. Ukuran gabah ternyata berpengaruh terhadap harga gabah. Pembeli lebih menyukai gabah yang berbentuk panjang dan lentik. Gabah yang pendek dan lebar harganya lebih murah dibandingkan gabah yang bentuknya memanjang. Oleh karena itu, hasil survey menunjukkan bahwa $56 \%$ petani menyukai ukuran gabah yang panjang $(6,61-7,50 \mathrm{~mm})$ dan $47 \%$ menyukai lebar gabah yang sedang.

Petani memiliki pereferensi masing-masing terhadap karakter aroma. Sebanyak $44 \%$ petani menyukai padi dengan aroma tidak wangi, $36 \%$ menyukai yang sedikit wangi, dan $20 \%$ menyukai padi yang wangi. Berbeda dengan karakter aroma pada karakter tekstur nasi sebanyak $92 \%$ petani menyukai tekstur nasi yang pulen, sedangkan $8 \%$ menyukai tekstur nasi yang sedang (Gambar 5). Kultur kedaerahan diduga berpengaruh terhadap kedua karakter tersebut. Di pulau Jawa Kebanyakan masyarakat memang lebih menyukai padi dengan aroma nasi yang tidak beraroma dan tekstur nasi yang pulen.

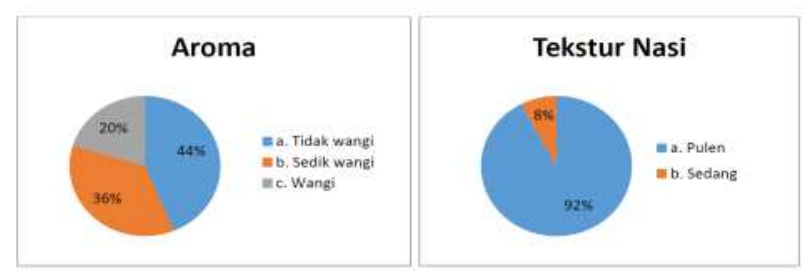

\section{Gambar 5. Prefeerensi Petani Terhadap Karakter Aroma dan Tekstur Nasi}

Hasil survey untuk karakter ketahanan, seperti ketahanan terhadap hama, ketahanan terhadap penyakit, ketahanan terhadap kekeringan, ketahanan terhadap genangan, dan ketahanan terhadap salinitas $100 \%$ responden menginginkan varietas padi yang tahan terhadap semua cekaman. Walaupun terbilang hal yang sangat sulit, namun tak ada salahnya ketika seorang pemulia tanaman berusaha untuk merekayasa varietas padi yang superior tahan berbagai macam cekaman dan mempunyai produktivitas yang tinggi.

Tabel 2. Persentase Kepentingan Masing-masing Karakter

\begin{tabular}{|c|c|c|c|c|c|}
\hline \multirow[b]{2}{*}{ Karakter } & \multicolumn{5}{|c|}{ Persentase Tingkat Kepentingan (\%) } \\
\hline & $\begin{array}{c}\text { Sangat Tidak } \\
\text { Penting }\end{array}$ & $\begin{array}{c}\text { Tidak } \\
\text { Penting }\end{array}$ & $\begin{array}{l}\text { Cukup } \\
\text { Penting }\end{array}$ & Penting & $\begin{array}{l}\text { Sangat } \\
\text { Penting }\end{array}$ \\
\hline Panjang Daun & 0,00 & 31,25 & $40,63^{*}$ & 28,13 & 0,00 \\
\hline Lebar Daun & 0,00 & 26,56 & $50,00^{*}$ & 23,44 & 0,00 \\
\hline Permukaan Daun & 1,56 & $54,69^{*}$ & 32,81 & 10,94 & 0,00 \\
\hline Tipe Malai & 0,00 & 9,38 & $45,31^{*}$ & 42,19 & 3,13 \\
\hline Cabang Malai Sekunder & 0,00 & 7,81 & 25,00 & 32,81 & $34,38^{*}$ \\
\hline Ketegaran Batang & 0,00 & 18,75 & 29,69 & $51,56^{*}$ & 0,00 \\
\hline Jumalah Anakan & 0,00 & 0,00 & 46,88 & $48,44^{*}$ & 4,69 \\
\hline Umur Tanaman & 0,00 & 0,00 & 15,63 & $46,88^{*}$ & 37,50 \\
\hline Ketahanan Terhadap Hama & 0,00 & 12,50 & 18,75 & 20,31 & $48,44^{*}$ \\
\hline Ketahanan Terhadap Penyakit & 0,00 & 0,00 & 3,13 & 10,94 & $85,94^{*}$ \\
\hline Ketahanan Terhadap kekeringan & 0,00 & 0,00 & 0,00 & 10,94 & $89,06^{*}$ \\
\hline Ketahanan Terhadap Genangan & 0,00 & 0,00 & 0,00 & 14,06 & $85,94^{*}$ \\
\hline Ketahanan Terhadap Salinitas & 0,00 & 0,00 & 0,00 & 14,06 & $85,94^{*}$ \\
\hline Produktivitas & 0,00 & 0,00 & 0,00 & 37,5 & $62,50^{*}$ \\
\hline Tekstur Nasi & 0,00 & 0,00 & 0,00 & 0,00 & $100,00^{*}$ \\
\hline
\end{tabular}

Keterangan: angka yang dikuti tanda * merupakan persentase tertinggi 
Selain keinginan petani dalam menentukan karakter tanaman padi, pada survey yang dilakukan juga dianalisis mengenai kepentingan masing-masing karakter menurut petani. Hasil survey menunjukkan bahwa karakter-karakter yang ditanyakan memilki kepentingan yang bereda-beda. Pada penelitian ini nilai kepentingan dibagi menjadi lima kelompok yaitu sangat tidak penting, tidak penting, cukup penting, penting, dan sangat penting. Pada karakter tinggi tanaman responden menilai karakter itu terbilang cukup penting menurut $45,31 \%$ responden. Begitupun pada karakter panjang daun dan lebar daun sebanyak 40,63\% menilai karakter panjang daun cukup penting, dan 50,00\% menilai bahwa karakter lebar daun memliki nilai kepentingan cukup penting (Tabel 2).

Hasil kajian dalam penelitian ini diharapkan menjadi salahsatu acuan bagi para pemulia tanaman untuk merekayasa tanaman padi yang sesuai dengan keinginan para petani. Petani sebagai pelaku kegiatan pertanian perlu difasilitasi bahakan diikut sertakan dalam kegiatan pemuliaan tanaman menggunakan terminologi parcipatory. Pada saat ini pemuliaan Tanaman Partisipatif telah dilakukan diberbagai tempat (Weltzien et al., 1999) dan mulai berkembang konsep-konsep bagaimana pola pengorganisasian kolaborasi antara petani dan peneliti dan metode pemuliaan apa yang paling sesuai. Pengetahuan yang sejajar antara peneliti dengan petani dalam beberapa tahap pemuliaan sangat penting untuk menjamin keberhasilan program, karena sebagian besar PTP dilakukan pada lingkungan marginal, dimana proporsi interaksi genotype $x$ lingkungan besar sedang heritabilitas rendah, merupakan hal yang harus dihadapi. Disisi lain petani dapat berkontribusi melalui pengetahuan mereka akan kualitas yang diinginkan dan karakteristik lingkungan yang menjadi target lingkungan.

\section{Kesimpulan}

1. Petani lebih menyukai tanaman padi yang memiliki tinggi tanaman, panjang daun, lebar daun, permukaan daun, sudut daun dan tioe malai yang sedang, cabang malai sekunder yang banyak, ketegaran batang yang kuat, jumlah anakan yang banyak, umur yang genjah, ukuran gabah yang panjang dan lebar, aroma yang tidak wangi, serta tekstur nasi yang pulen.
2. Petani beranggapan bahwa karakter permukaan daun merupakan karakter yang tidak penting; karakter tinggi tanaman, panjang daun, lebar daun, sudut daun, tipe malai, panjang gabah, lebar gabah, dan aroma tergolong karakter cukup penting; karakter ketegaran batang, jumlah anakan, dan umur tanaman merupakan karekter yang penting; karakter ketahanan terhadap hama, ketahanan terhadap penyakit, ketahanan terhadap kekeringan, ketahanan terhadap genangan, ketahanan terhadap salinitas, produktivitas, dan karakter tekstur nasi merupakan karakter yang sangat penting.

\section{Daftar Pustaka}

Abdullah, S. 2004. Pengaruh perbedaan jumlah dan umur bibit terhadap pertumbuhan dan hasil padi sawah. Dalam Lamid, Z., et al. (Penyunting). Prosiding Seminar Nasional Penerapan Agroinovasi Mendukung Ketahanan Pangan dan Agribisnis. Sukarami, 10-11 Agustus 2004; 154-161 hlm.

Adnyana, M.O., Munarso J.S., dan Damardjati D.S. 2004. Ekonomi Kualitas Beras dan Selera Konsumen. Di dalam: Kasryno F, et al.(eds). Ekonomi Padi dan Beras Indonesia. Badan Penelitian dan Pengembangan Pertanian. Departemen Pertanian

Almekinders, C.J.M. and A. Elings. 2001. Collaboration of farmers and breeders: Participatory crop improvement in perspective. Euphytica, 122: 425 - 438.

Baihaki, A., dan N. Wicaksana. 2005. Interaksi genotip $\mathrm{x}$ Lingkungan, Adaptabilitas, dan Stabilitas Hasil, dalam Pengembangan Tanaman Varietas Unggul Di Indonesia. Zuriat, Vol. 16, No. 1: 25 - 38.

Gani, A. 2003. Sistem intensifikasi padi (System of Rice Intensification). Pedoman Praktis Bercocok Tanam Padi Sawah dengan Sistem SRI. BPTPH Provinsi Jawa Barat.

Heriyanto, K., dan Ruly. 2015. Dinamika Preferensi Petani dan Penyebaran Varietas Unggul Kedelai Di Propinsi Jawa Timur. Jurnal Cakrawala, Vol. 5 (2) : 115 - 124.

Kawano, N., Ito O., and Sakagami J. 2009. Morphological and physiological responses of rice seedlings to complete submergence (flash flooding). Annals of Botany. 103: 161-169.

Kisman, Nurul K., Trikoesoemaningtyas, Sobir, 
dan D. Sopandi. 2012. Karakter MorfoFisiologi Daun, Penciri Adaptasi Kedelai terhadap Intensitas Cahaya Rendah. Buletin Agronomi, Vol. 35 (2): 132 - 144.

Marwan, Asri. 1990. Marketing. BPFE Universitas Gadjah Mada. Yogyakarta

Mulyani, A. 2008. Potensi dan Ketersediaan Lahan untuk Pengembangan Kedelai di Indonesia. Warta Penelitian dan Pengembangan Pertanian, Vol. 30 (1): 18 - 29.

Ningsih, Riani dan Dwi Rahmawati. 2017. Aplikasi Paclobutrazol dan Pupuk Makro Anorganik Terhadap Hasil dan Mutu Benih Padi (Oryza Sativa L.). Agriprima, J. of Applied Agric. Sci., Vol. 1(1): 22 - 34.

Noer, Hasmari. 2013. Prospek Pengembangan Tanaman Pangan Pada Lahan Kering Ditinjau dari Keputusan Petani dalam Menerapkan Teknologi Usahatani (Suatu kasus pada Petani Tanaman Pangan Lahan Kering di Kabupaten Morowali Provinsi Sulawesi Tengah). Disertasi Doktor Program Pascasarjana Universitas Padjadjaran.

Prayoga, M. Khais., Meddy R., dan N. Wicaksana. 2016. Penampilan Karakter Daya Hasil 15 Genotipe Kedelai hitam (Glicyne soja (L.) Merr.) Pada Pertanaman Tumpangsari dengan Jagung. Jurnal Agrikultura, Vol. 27 (2): 21 - 33.

Rachmawati dan Retnaningrum. 2013. Pengaruh
Tinggi dan Lama Penggenangan Terhadap Pertumbuhan Padi Kultivar Sintanur dan Dinamika Populasi Rhizobakteri Pemfiksasi Nitrogen Non Simbiosis. BionaturaJurnal Ilmu-ilmu Hayati dan Fisik, Vol. 15 (2): 112 - 125 .

Ruminta. 2016. Analisis penurunan produksi tanaman padi akibat perubahan iklim di Kabupaten Bandung Jawa Barat. Jurnal Kultivasi Vol. 15(1) : $37-45$.

Suyamto dan Widiarta. 2008. "Kebijakan Pengembangan Kedelai Nasional". Simposium dan Pameran Teknologi Aplikasi Isotop dan Radiasi. Jakarta.

Sundari, T. 2012. Karakter Kuantitatif Kacang Hijau pada Lingkungan Naungan. Buletin Penelitian Pertanian Tanaman Pangan VOL. 31 (1): 42 - 55.

Syahri dan Renny. 2013. Respon Pertumbuhan Tanaman Padi Terhadap Rekomendasi Pemupukan PUTS dan KATAM Hasil Litbang Pertanian di Lahan Rawa Lebak Sumatera Selatan. Jurnal Lahan Suboptimal, Vol. 2 (2): 170 - 180.

Tampoma, W.P., T. Nurmala, dan M. Rachmadi. 2017. Pengaruh dosis silika terhadap karakter fisiolog1 dan hasil tanaman padi (Oryza sativa L.) kultivar lokal poso (kultıvar 36-Super dan Tagolu). Jurnal Kultivasi Vol. 16 (2) : 320 - 325. 